\title{
Ceremony, Tongkonan and the Memories of Toraja People (Consecration Ceremony for Traditional House in Toraja, South Sulawesi)
}

\author{
Susia Kartika Imanuella \\ Sinode Gepsultra \\ Kendari, Indonesia \\ susia.kartika@gmail.com
}

\author{
M. Yoesoef \\ Sinode Gepsultra \\ Kendari, Indonesia \\ yoesoev@yahoo.com
}

\begin{abstract}
Tongkonan, aside from being home for Toraja people and as an identity marker, is also functioned as a center of daily activities for Toraja people. Tongkonan could not run its function without having a consecration ceremony called Mangrara Banua. Mangrara Banua is a traditional ceremony held for the recently finished Tongkonan or the rennovated one. Ethnographically, Mangrara Banua is not only seen as a ceremony for celebrating the newly built Tongkonan, more than that, Mangrara Banua occurs to recall the memories of Toraja people about their exsistence as an indigenous people, through the spoken narratives in the ceremony.
\end{abstract}

Keywords: Mangrara Banua, Tongkonan, Toraja People, Memories

\section{TONGKONAN: A CENTER OF TORAJA PEOPLE LIFES}

"Because a house is the center of everything, for either agriciltural activities and stockbreeding, or even marriage ceremony. Without a house, what would a human be? House is the center of everything, place to sleep, to cook rice, or a living place for all existence, either crops, livestock and even the existence of human itself."

Sentences above are cited from an interview with a Tominaa, one of Aluk Todolo customary leader who often called Ne' Tato Dena. Aluk Todolo seen as the ancestor's believe; in which belongs to the ancient Toraja people and is full of customary rules, prohibitions, punishments, and also methods of conducting the customary ceremonies in this case including Rambu Solo' (funeral ceremony) and Rambu Tuka' (thanksgiving ceremony). Within its doctrine, Aluk Todolo or Alukta said as a religion inherited by Puang Matua (God) to the first born human, Datu La Ukku' (Bujis 2009:27;Tangdilintin 2014a:54).

Based on Ne' Tato's interview above, the writer begins to understand the specialty of a building which has become Toraja's pride all this time. A house which for them is not only meant as a building to live in but rather, more than that, a house named Tongkonan by them is also reputed as a human body that became the center of the living (Waterson, 2009:183)

Etymologically, 'Tongkonan' originated from the words tongkon or ma'tongkon in Toraja language which means 'to sit' (Tangdilintin, 2014b:39; Nooy-Palm, 1979:231). Words ma' tongkon or tongkon for Toraja people literally aren't pointing towards some activities as we generally understand. Literally, tongkon means to sit, to discuss, to gather, to reach for an agreement, a conference, in which they discuss every sort of problems together to find the solution, or sit -in which they establish customary rules to apply in the society. And as added by Tammu and Van Der Veen in Adams (2006:80), the word ma'tongkon refers to the activities of Toraja people within the grasp of the ceremonial context.

Tongkonan has an important role as a place in where customary ceremonies are held, and at once as someone's social marker in society. This sense explains that the name Tongkonan for Toraja's Traditional House is referring to its function, not to the physical form or the architecture. Nowadays, Tongkonan has become the identity for Toraja people (Volkman, 1990:92; Waterson, 2009: 195), even though not all of Toraja's traditional house can be categorized as Tongkonan before identifying its function first. Then in this case, what function has to be had by a traditional house before we can call it Tongkonan?

Marla Tandirerung, Toraja's cultural scientist who has been keeping Tongkonan Buntu Pune from her Ancestor said,

"Actually, not all traditional house in Toraja can be called Tongkonan, because Tongkonan is a name only for a house with a customary function"..

\section{MANGRARA BANUA FOR TONGKONAN}

Role, purpose, status and the prestige of a Tongkonan is not only judged by its physical appearances, such as its physical form, its carving or the number of the buffalo horn attached to its pillars, but also judged from the consecration ceremony called Mangrara Banua. This consecration ceremony has become one means to legitimate the status and Tongkonan's function in society.

It is through this ceremony also, the collective memory or Toraja people will be presented to recall their origins, role, and the status of the Tongkonan in society, along with the generations inherited it. As expressed by Vansina (1985:xi), the memory of an oral society has become a vault in which the whole past experience of human is stored, and also can help explain today's social condition. Memory delivers a culture of society from one generation to another.

Mangrara Banua ceremony, not only functioning as a media to recollect all those collective memories. It is a prestige to finally complete the building and then performing that consecration ceremony, because for Toraja people, no matter how luxurious a physical appearance of a Tongkonan is, without ever having a Mangrara Banua ceremony, the 
building would only bring shame to the whole family. The duty to perform the ceremony also explained by Ne' Tato.

"it is an order from our ancestor to us to build a house. So that we can continuously be safe and well, we must perform the ceremony. Either for the construction or any other ceremony.

Mangrara Banua ceremony has a different form along with the different rules in each area where it will be held. In this research, I would especially describe one of Mangrara Banua ceremony held for Rampunan Tongkonan belong to Nek Roswita in Luak, Bungin District, North Makale Subdistrict Tana Toraja, from August 18th to 21th in 2016.

\section{PHASES OF MANGARA BANUA CEREMONY}

\section{A. Manta'da: Self 'purification' before entering the ceremony}

The first day of the ceremony is a preparation phase called Manta'da, which held before going to the main phase (Mangrara Banua). Manta'da itself mean as a 'cleaning' process, or as named by Van Gennep (1960:20) as a purification phase, is a preparation phase where all families from Rampunan Tongkonan gather to offer a sacrificial pig for The Lord, represented by the church, in order to 'cleanse' or to purify themselves from every mistakes and misunderstanding made during the process in building the Tongkonan.

Tongkonan that is about to ordinate has been decorated with various decorating beads on it's rooftop. From kandaure (local Toraja's colorful beads handicraft) attached to every pillar on the rooftop, along with old clothes named sarita - a long cloth which has been passed over generations, and maa (a short version of sarita) as a nobility marker of the owner of the Tongkonan. This cloth only used on great ceremonies in Toraja, one of them is Mangrara Banua. Every accessory presented in the ceremony is not only as a pleasure for the eyes but also as a marker of social acceptability of the owner of Tongkonan.

Mangrara Banua ceremony for Rampunan Tongkonan held in Christian form as a religion followed by the owner, resulting every phase of the ceremony always started with a religious service. The service starts the phases of the Tongkonan consecration ceremony for the next three days, also as the symbol of gratitude for the finished Tongkonan. This service is also as a turning point to start the consecration ceremony, to 'purify' themselves from every mistake and misunderstanding during the construction process.

For Toraja people, 'purification' process at the consecration ceremony is not only valid for the Tongkonan and the neighborhood around, but also for each of the family member who participated during the whole construction and ceremonial process. This 'purification' process is also an entrance door to the Mangrara Banua ceremony.

\section{B. Ma'tarampak: Blood and party's decoration}

Ma'tarampak is a phase on the second day of the ceremony to mark the installation of the lower part of the rooftop. Actually, this installation has been done long before the Mangrara ceremony is held. Still, this lower part of the rooftop is re-installed at the second day of the ceremony as the symbol of gratitude. Ma'tarampak on the second day of the ceremony is the early phase of Mangrara Banua or the consecration ceremony of Tongkonan.

Ma'tarampak phase is marked with Ma'pakande Ada process, which is the slaughter of the sacrificial pigs from the first day of the ceremony. Pork slices then distributed to each of the customary chief in the area, such as to parengnge (a noble title back in pre-colonial era: A customary government position to rule above a settlement of Layuk and kaparengesan Tongkonan (Waterson, 2009:474), and tominaa (customary leader for Aluk Todolo) according to their role in the custom. Pork slices also distributed to nearby customary Tongkonan.

Literally, Ma'pakande means 'to feed', whilst Ada means 'custom'. This process held as a symbol of the owner's gratitude to all of the customary chief and the church for their service for the society by giving them certain parts of the porks. Ma'pakande'Ada process started by slaughtering dozens of pig offered by the family. The meat then roasted, sliced accordingly to the custom rules, and then certain parts of it are given to each of the customary chief presents.

The distribution of the meat is not only for the participating customary chief in the region such as To Parengnge and Tominaa as the customary leader of Aluk Todolo whom in charge of leading the religious ceremony but also for the church which nowadays taking the role of replacing Aluk Todolo in the customary ceremony. Besides being the symbol of gratitude from the Tongkonan owner, Ma'pakande Ada process also held to gain the legitimacy of the society for the social acceptability and for the role of their Tongkonan in the custom order.

\section{Massomba Tedong: The prayer for the buffalo}

Approaching midnight, on the second day of the Mangrara Banua ceremony, a tied up black buffalo on a huge tree east of the Tongkonan is prepared as a sacrifice in massomba tedong process that evening. Massomba Tedong is a part of Mangrara Banua process for Rampunan Tongkonan. This part of the process is called Merok ceremony - a ceremony of the highest level of Mangrara Banua, which often marked with the sacrifice of a black buffalo, and can only be done by Layuk Tongkonan who has held Ma'bua ceremony (a grateful ceremony to pray for wealth and prosper) beforehand.

Unlike the chosen big-striped-long horn buffalos at the funeral ceremony, the chosen buffalo for sacrificial in massomba tedong is a black and short horn (around half of the man's arm) buffalo. As the chosen sacrificial buffalo, it must have eight point-like white spots at its skin, only with that condition the buffalo will be considered worthy as a sacrificial buffalo in massomba tedong.

Massomba tedong by Ne' Tato Dena as a Tominaa, specifically for gratitude ritual, held in form of a prayer including praise on the sacrificial buffalo for all night long. While Adams (2006:249) gave the definition of Passomba Tedong as a series of prayers addressed towards the buffalo; a traditional ceremony related to the consecration of the Tongkonan.

In one of the Passomba Tedong's poem of Merok ceremony, telling a story of our ancestor's buffalo behalf on the order of Puang Matua to sacrifice itself for the human. Even though the ancestors of human and animal were created at the same time by Puang Matua, but unlike buffalos, only 
human knows how to make a ceremony to worship The Lord. Therefore the buffalos were pointed as sacrificial for the ceremony. This story of the buffalo's origin became something important to tell in Massomba Tedong ceremony, as cited from Waterson,

\begin{abstract}
"Kamu to siulu'ki lanmai sauan sibarrung, apa kami mo torro to lino tu la memala' menumba langan To $\mathrm{Tu}$ Mempa'ta, na iatu ladipenomban, susimo tu kada misiosso'i diomai nene'mu lanmai sauan sibarrung." (Waterson, 2009:299)

You are our brother born from the hands of Puang Matua, but only us, humans, able to held sacrificial ceremony to praise The Lord, and you are the only one to sacrifice; as the order inherited by your ancestors.
\end{abstract}

Massomba Tedong ceremony which is held on that night at Rampunan Tongkonan, led by a priest from one of the Protestant Church in Toraja. The sacrificial buffalo then released from its binding and then marched towards Tongkonan right in front of the platform where the priest standing. Dressed in arobe as a ceremonial vestment, and a red passapu' (head accessory with a pointed part heading towards the sky) on his head, and a spear as a symbol held in his left hand, the priest then started to say the Passomba Tedong prayers,

\section{* “Kurre, kurre, kurre sumanga'na, langan Puang dao tangana langi'}

Sampa' parayanna di patuara' langngan to kaubanan dao ma'arru' balusunna langi' kalua'.

We give our gratitude only for The Lord in the sky

Kurre tua'na te padang tuo balo' pole parayanna te padang tumbo kumuku'

Praise The Lord for this universe

Kurre sumanga'na te timpolok maa' pole parayannate tetuk doti langi'

Praise The Lord for the Maa

to lamban, pole parayanna te darrak to unnorong

Praise The Lord for the Sarita

Kurre sumanga'na te sendana bonga, pole parayanna te tallu basongna

Praise The Lord fot the sandalwoods

Kurre sumanga'na tokonan tedong, pole parayanna pandanan bai

Praise The Lord for the buffalos

Kurre sumanga'na lantang ma 'pampang, pole parayanna barung ma'dandan

Praise The Lord for the ceremonial huts

Kurre sumanga'na pangkungan bai, pole parayanna kale'ke karambau

Praise The Lord for the pigs
La tengka tedongpa randan di pudukku, lako tedong ma'buluk aluk, la te'papa dara' lengko di lilaku lako karambau ma'songgo bisara

I will keep on telling story about the bufalos

Pa torro magiang iko nene' mendeatammu umpolalan eran di langi' apa tongkon to malaya' iko todolo kapuanganmu umpolambanan enda' to palullungan. Umpolalan ia sibidanganna langi umpolambanan ia siamma' na batara umpemanukki mi pangala' tamman umpellalundunni kurra manapa' anna torro memba 'ka 'lan pangala' tamman anna mala' marapuanmi lan kurra manapa' ia ri na randuk di tiro lindo nene'mu po nene' ia ri na mamula di pemanta perupa todolo kapuanganmu manapo ri bangunan banua, robok ri isungan pentiongnan, anna dilando lalanni pong sabannangna rekke ulunna salu kalua' anna di langka pa'taunanni pong koe koe rekke tiparitik na uai.

Once upon a time, your ancestors were frightened to climb the ladder in the sky. Instead, they were settling in the forest and proliferate. When the human settlement was collapsing, they enter the forest to find lumber to repair their houses. It was the time they met the buffalo.

Iko mo ladi penomban langngan Puang Di Matua, tedao to tumampa rara'ta pemala'na to ma'rappu tallang, pangallonanna to ma'kaponan ao'...

The one to be sacrificed and tributed from the whole family for The Lord.

*text and translation by Priest Samuel Panggalo (2017)

Passomba Tedong chanted by Priest Samuel which he confessed was a 'simplified' form and been adjusted with Christianity context because at first this liturgy was originated from the Aluk Todolo belief inherited by the ancestors of Toraja people. It is just, as previously explained by NooyPalm (1979:138), that some first parts from Massomba Tedong consist of prayers of adoration for The Lord. This matter considered in contradiction with the belief of Toraja people, whom mostly Christian. To ask them to put their faith back on giving 'power' to other existence besides The Lord, is just the same as paganism, says Priest Samuel,

"Truthfully, Massomba Tedong original version is Aluk Todolo's version. But, I have replaced the godsworshipping part with prayers to The Lord"

In Toraja, either Catholic or Protestant churches were not establishing rules to ban certain ceremony or tradition of Toraja people. Nevertheless, the churches are doing their best to 'modify' some of the tradition which contradicts with their rules. This is exactly what happenes to Mangrara Banua ceremony, and even to Massomba Tedong as a part of the ceremony. The concept of worshipping gods and ancestors in Massomba Tedong has been fully replaced with worshipping The Lord according to Christianity. But this modification in Massomba Tedong does not change its role and function as a gratitude in the consecration ceremony.

\section{Ma'bumbun Lolo and Ma'bubung: Spectacle of blood and flesh}

A quite interesting sight in that morning starts the series of ma'bumbun lolo. People marching with pigs placed inside of a box-shaped litter called lettoan, with Toraja's special 
carving on each side, colorful Maa attached on it, plus a redcolored leaf on top of it. This march performed by the bloodrelated family and the descendant of Rampunan Tongkonan.

Every person who came and bring pig must introduce their parentage, which Tongkonan they came from, or their grandparents name. By doing so it will be easy to recognize them. Pigs offered can be rejected by Nek Roswita and family as the owner of Tongkonan if they're not finding themselves blood-related with the person who offers them a pig. It is necessary so that not every person can claim themselves as a descendant of the owner of Tongkonan (Waterson, 2009:194).

Ma'bubung process as the final part of Mangrara Banua ceremony, start in the middle of the day. Different from ma'bumbun lolo, only few people stationed inside the granary. The service was done together with the prayers as a symbol of gratitude in completing the whole process of Mangrara Banua ceremony according to plan. After the service end, all family members who present to begin the mantanan sendana (sandalwoods planting) at the eastern side of the Tongkonan right where the buffalo slaughtered in Massomba Tedong.

Sandalwood is one of few plants beside barana' which taken sacred by Toraja people. This plant has been associated as a sign of wealthy life, as cited from a spoken narrative in Merok ceremony (Waterson, 2009:177),

Kurre sumanga'na te sendana sugi, saba' parayannate kayu mentengke ianan.

Praise The Lord for the sandalwood, for the overflowing blessing on its branch that contains noble things.

Sandalwood tree planted on the east side of the Tongkonan, will then become the symbol of a grand consecration ceremony, along with Bate' and buffalo as it's marker. Sandalwood also has taken as a reminder to restore the memory of the whole family, even the whole community of Luak, for the silence and the merry-ness of Mangrara Banua for Rampunan Tongkonan.

\section{MEMORY OF TORAJA PEOPLE, HERITAGE OF THE ANCESTORS}

\section{A. Nurturing memory with spoken narratives}

Massomba Tedong narratives by Priest Samuel at the Rampunan Tongkonan consecration ceremony started with a gratitude towards The Lord as the creator of everything that exists. Then the gratitude for every element of the ceremony such as Maa, Sarita, Sandalwood, buffalo, money, spear, and Keris. These things presented in Passomba Tedong narratives are not just to complete the poem. Everything has mentioned are the symbol of nobility, wealth and prosperity, and can only present in consecration ceremony for the Tongkonan which held an important role in traditional government such as Layuk or Kaparengesan Tongkonan.

After paying gratitude for each of the material elements in the ceremony, the priest then continues his narrative and start to tell a story about the origin of the buffalo's ancestor. He starts his story as if he is talking with the sacrificial buffalo, delivering the story about the terms made by the buffalo's ancestor with Puang Matua as a sacrificial for human life. Along with sweet praise to won its heart, so that every part of its body would bring prosper for the whole family member of the Tongkonan.
On the last part of the prayer towards the buffalo, every part of its body made as pieces of jewelry for the whole family. It is a sign that every part of its body sacrificed as a precious jewelry belongs to the family, and pray that every part of it is a blessing flows inside the Tongkonan.

Every time the narratives in Passomba Tedong are spoken through reading as Priest Samuel does, or through other pure spoken narratives like Tominaa, are the manifestation of a message containing the collective memory of Toraja people, not only about the ordinated Tongkonan of their ancestors, but also the relationship between human and buffalo since the beginning of their time.

In his explanation about spoken narratives, Ong (2013:211) revealed that narratives are an important part in primary oral culture for its capabilities to bind a huge number of tradition and knowledge in a relatively long, big, and everlasting form, and it's function to bind thoughts more permanently. This kind of capability is shown by Toraja people in Massomba Tedong. This ceremony is not only keeping the memory of the origin of ordinated Tongkonan, but also a great history of Toraja people about their ancestor origins, and their identity as a largely indigenous people. Indirectly, this consecration ceremony helps to nurture the way of life inherited from their ancestor.

Their way of life is not only about customary ceremonies to held, more than that it's about the way of life in which they maintain the harmonic relationship between human and nature and The Lord. Through believing the existence of buffalo as a part of the origin of Toraja people, providing lumber for the Tongkonan, and also planting sandalwood at the last phase of the consecration ceremony, they have shown us how to nurture relationship among themselves, to nature and The Lord, through collective memories inherited in their community.

Mangrara Banua as a manifestation of their life's value truly originated from their bonds with nature (animals and plantation), among human, and The Lord. Without the presence of those three, ceremonies wouldn't have survived all this time. The needs of Toraja people to held ceremonies proof that their existence also requires them to honor and maintaining their relationship with The Lord, with other humans, and nature as their heritage.

\section{B. Nurturing 'Memory' in custom and religious dynamics}

Consecration ceremony for Tongkonan, at the current implementation, has changed significantly since Christianity dominates the matters between Toraja people and The Lord. It is clearly shown in consecration ceremony for Rampunan Tongkonan in Luak. The shift of the divinity concept, from their faith towards gods and their ancestor as the ultimate sacrifice, became Gods of heavens, also contribute in changing the form of the ceremony.

What can the writer observe from this Christian version of Mangrara Banua ceremony are phases of the ceremony, the manifestation of symbols, and sacrificial animal, still consistently following the rules in Alukta. Most significant changes in Mangrara Banua ceremony is the form of prayer and to whom the animal sacrificed to. In this case, there is some sort of paradox in doing tradition. At one side they believe in Jesus Christ, but at the same time, they still use the rules in Alukta when it comes to the ceremony. 
In the middle of the collision between their ancestor's belief (Aluk Todolo) with the concept of Christianity in Toraja, there are some people who maintain certain parts of their tradition and does not follow the changes. This effort showed in the division of Aluk Todolo into two separate forms, Aluk, and custom. Aluk consist of every form of ritual service toward their ancestors and gods. As for custom, consist of rules in holding the ritual and live as one indigenous people. Through this division, Toraja people who follow Christianity as their religion must refrain themselves from every ritual practices that related to Aluk but still bounded with the terms and rules of their custom.

In the case of Mangrara Banua for example, the Aluk's part is the praise and sacrifice made for their gods and ancestors which then changed into service and sacrifice to The Lord. Whilst the process of holding the ceremony in three days according to the role of the Tongkonan soon to be ordinated, the types and numbers of the animal to sacrifice, and every other established terms in holding Mangrara Banua Ceremony is the case of custom. Custom, as the permanent element in the ceremony, then 'adjusted' with the concept of Christianity settled by the churches in Toraja.

The effort to maintain an element in Aluk Todolo, which is custom, and removing other elements can be seen as a form of negotiation done by Toraja people so that they still can display certain 'memories' of custom within the constant pressure and impact of egalitarianism in Christianity concept which would like to remove hierarchical system long inherited by Toraja people (Bigalke, 2014:189)

If spoken narratives in Passomba Tedong used as a media to nurture memories related to the origins of Toraja people, and to maintain their relationship with nature and The Lord, then the materialistic elements shown in ceremony such as Bate', buffalos, pigs, and decorating ornament of the ceremony, used as a media to recall their memories concerned with their social acceptability as indigenous people

Bate' along with the pa'manuk londong and pa'barre allo, sandalwoods, and old clothes twisted around the north part of Tongkonan's roof, and other decorating ornaments marking the ordinated Tongkonan as Layuk Tongkonan or Kaparengesan, which considered as the most respected and the highest level as the customary Tongkonan in Toraja. Not every Tongkonan that would soon be ordinated can wear this ornaments during the ceremony. Batu A'riri Tongkonan for example, as the Tongkonan of the family who unrelated to the customary government, is not allowed to wear pa'manuk londong or pa'bare allo on it's Bate', or to plant sandalwood at the end of the ceremony. If they break that law, the owner of Tongkonan and their descendants will be punished according to the custom rules by the elders. It is much worse if they use buffalo as their sacrificial animal for their Tongkonan's consecration ceremony. Buffalo in Mangrara Banua ceremony is taken as the highest level of sacrifice which can only be presented in Merok ceremony by Layuk or Kaparengesan Tongkonan at the highest gratitude ceremony or Ma'bua. If the ordinated Tongkonan doesn't have relation with Layuk or Kaparengesan Tongkonan, then the sacrificed animal to present are chickens or a pig.

This materialistic element in Mangrara Banua ceremony is used to recall their memories, that their ancestors are not only inherited them spoken narratives, which record their origin as indigenous people along with their value of life to maintain their relationship with nature and The Lord through planting sandalwoods or sacrificing animals. Another important heritage is the social order or social structure which divides the noble family (the elite in Toraja), with the regular people. This structure has been 'nurtured' through customary ceremonies, especially Mangrara Banua.

Not only focusing about the materialistic element of the ceremony, process of meat distributing or Ma'pakande Ada' and feast, as added by Jong $(2013: 189,194)$ as the most visible form of Siri' (in concern with honor or prestige) for Toraja people. Jong saw how the portion of the meat shared are varied according to their social acceptability, and names of people to receive it will be called loud enough by the priest through speakers. Therefore, those names would be the center of attention of the people because the portion of meat received will be the marker of their social acceptability. Food sharing in a ceremony also become a form of Siri' that is highly visible during the process. Food sharing in large scale is important to express Siri' in a ceremony, just as the numbers of the animal slaughtered, and many other materialistic elements presented during the ceremony.

Yet, no matter how big the impact caused by Christianity to change their service in Mangrara Banua, it still unable to change the role of this ceremony as a media to display their social acceptability and a prestige of the elites in Toraja. Eventually, the writer would understand that changes made in Mangrara Banua ceremony are limited only to the part where they practice worship or their beliefs to gods and their ancestors through sacrificial animals.

The purpose of the effort from certain groups to separate Aluk from custom so that the hierarchical system that grows as part of Toraja people's custom was not abolished along with the practices of worshipping gods and ancestor. So that they could still gain access as the top of the elites. Losing their social acceptability, especially as elites would cause them losing control over kaunan/slaves along with the oppressive instruments.

Making religion as their reason, Toraja people have abandon all kinds of thing that related to worshipping practices towards gods and ancestors, but still they find it difficult to release themselves from a system that placed them on the top level or the social structure, in fact, choosing it as a part of ceremony that worth to maintain, and must be shown in every chance. Bigalke (2014: 194) revealed the lines of the social structure are not changing, as a matter of fact, it is lasting, even among Christian followers. To him, this is a form of a Torajanized Christianity that is far more powerful than Christianized Toraja.

\section{CONCLUDING REMARKS}

Oral tradition in the form of Mangrara Banua ceremony is a proof of human intelligence to remember and transmit complex ideas and important messages contained in the memory of indigenous peoples, in a sustainable manner from time to time. The songs and prayers presented in the ceremony acted as a media link between humans and the Creator. Even though such things are often regarded as human actions based on myth alone, on the contrary, the Toraja people actually prove through the Tongkonan consecration ceremony that these actions (ceremonies) are based on rational reason which 
aims to create a balanced relationship between the three cosmic entities, namely the Creator, human, and the nature. Toraja people are based on an instinct which then encourages them to worship the highest power which has a concrete form in the natural order, as well as its relationship to the problems of life and death.

Human experiences in relation to the Creator, nature and fellow human beings, then expressed and transmitted through the ceremony. This experience was present at the Mangrara Banua ceremony, one of which was through the manta'da process which was marked by the installation of Bate'. Bate' which is used as a marker of the social status of the Tongkonan, is also used as a communication media between humans who are on earth with the deata and Puang Matua in the sky. Bate' which is made of bamboo, is believed to be descended from the sky by the deata to protect humans from danger and disease. The shape is large and long as if it resembles a hand that descends from the sky to help humans on earth. Likewise the massomba tedong process, Buffalo becomes a valuable 'jewelry' that is owned by the Toraja people to be presented as a form of their gratitude for the blessings received from Puang Matua.

Unlike the Ma'pakande Ada' stage, the concept of 'sharing the meal' both at meals and in the process of sharing meat is intended as a stage of unification with a community group order. The concept of food sharing is a way to unite bonds with the community or community where the Tongkonan is located. Recognizing its essence as an indigenous community, the Toraja use the Mangara Banua ceremony into a living space to strengthen social bond and build a sense of solidarity, not only through the process of distributing meat but also the process when everyone involve in building Bate', preparing meals, and their spontaneity to sing and dance together to follow the music of joy in the ceremony.

\section{REFERENCES}

[1] Adams K M 2006 Art as Politics (Honolulu: University of Hawai'i Press)

[2] Nooy-Palm H 1979 The Sa'dan Toraja: A Study Of Their Social Life and Religion (Leiden: Koninklijk Instituut voor Taal-, Land-en Volkenkunde)

[3] Ong W J 2013 Kelisanan dan Keaksaraan (Yogyakarta: Gading Publishing)

[4] Rappoport D 2014 Nyanyian Tana Diperciki Tiga Darah (Jakarta: Kepustakaan Populer Gramedia)

[5] Sande J S 1986 Passomba Tedong Sastra Lisan Toraja (Jakarta: Proyek Penerbitan Buku Sastra Indonesia dan Daerah)

[6] Schechner R 2003 Performance Theory (New York: Routledge)

[7] Tangdilintin L T 2014a Toraja dan Kebudayaannya (Makassar: Lembaga Kajian dan Penulisan Sejarah Budaya Sulawesi Selatan)

[8] 2014b Tongkonan Rumah Adat Toraja: Arsitektur dan Ragam Hias Toraja (Makassar: Lembaga Kajian dan Penulisan Sejarah Budaya Sulawesi Selatan)

[9] Van Gennep A 1960 The Rites of Passage (Chicago: The University of Chicago Press)

[10] Vansina J 1985 Oral Tradition as History (Wisconsin: The University of Wisconsin Press)

[11] Volkman T A 1985 Feasts Of Honor (USA: University of Illinois Press)

[12] Waterson R 2009 Paths and Rivers Sa'dan Toraja Society Transformation (Netherlands: KITLV Press 